\title{
Professional deontology, self-regulation and ethics in the Information Society
}

\author{
Jacques Berleur
}

IFIP-TC9 and SIG9.2.2 Chair, Institut d'Informatique, Cellule interfacultaire de Technology Assessment (CITA, Facultés Universitaires Notre-Dame de la Paix, B. - 5000 NAMUR

jberleur@info.fundp.ac.be, http://www.info.fundp.ac.be/ jbl

Abstract: IFIP (International Federation for Information Processing) has been working on professional codes of deontology for the last 10 years. Lessons have been derived from that experience and most probably are also applicable in the more general field of engineering, especially when related to the Information Society. Today there is an emphasis on instruments of self-regulation in a society where it is said that legal instruments are territorial and not global. IFIP-Special Interest Group 9.2.2 has proposed a classification and has made an analysis of some of these instruments. Specific domains come forward when building a framework for regulating the Information Society. Professional deontological statements in most cases show an ethical preoccupation. The question may be raised whether this is to protect customers, clients or citizens, or whether this is for self-protection. How to implement these ethical considerations and instruments remains a challenge to be examined in the framework of the World Summit on the Information Society.

Key words: codes, deontology, IFIP, professional ethics, self-regulation 


\section{PROFESSIONAL ETHICS IN ENGINEERING AND SCIENCE}

The term 'Professional deontology' is not yet fully accepted in the English terminology, but may be thought equivalent to others such as 'Code of Conduct', 'Code of Ethics', 'Guidelines', 'Standards',... Deontology refers often to the I. Kant's theory, and is used mostly in the Latin area, whereas ethics is more accepted in certain circles, mainly Anglo-Saxon, although there are also people that advocate that ethics is personal whilst professional conduct may be defined at the level of a profession: medical practitioner, lawyer, architect, engineer,... The vocabulary is far from being stable.

The relevance of ethics for engineers seems obvious de facto. One could be convinced by consulting the Institute of Electrical and Electronics Engineers (IEEE) 'Ethics Resources and Organizations'; or the resources, products and services of the National Institute for Engineering Ethics (NIEE). Let us select the Online Ethics Center for Engineering and Science (OECES) at CASE Western Reserve University. It seems to us a 'must' in the domain. We find there educational resources, reference material, cases, essays, and examples of Codes, maintained by the OECES itself as well as by other organisations (OECES, 2003). Interesting is also the index of topics addressed on the OECES, which reveals the kind of preoccupation that pervades the domain of activities and research:

- Confidentiality (trade secrets, database confidentiality,...) and other

General Ethical Issues (lying, deception, negligence, accountability, corruption,...);

- Disciplines (Engineering [civil, electrical, environmental, nuclear], Computer Science,...);

- Diversity (general, race and culture, gender and sex);

- Educational Issues / Workplace Settings Issues (conflicts of interests, safety, design, pedagogy, competency, environmental issues, financial fraud, scientific fraud, gifts and payments, professionalism, copying, quality, risks, organisational and ethical responsiveness,...);

- Ethics Education (engineering, research, computer);

- Famous Cases;

- Legal (property, intellectual property, proprietary knowledge);

- Research Conduct (general, Internet, conflict of interest, mistake, publication and credit, research subject, working relationships).

We shall come back later on these issues after having discussed the Professional Ethics for Computer Professionals. The OECES site is 
unfortunately nearly totally US centred, as well as the others that we have mentioned, even if IEEE has international audience.

This does not mean that work is not done elsewhere: the European Ethics Network gathers more than 120 institutions throughout Europe (EEN 2003). It has a Journal, Ethical perspectives: Journal of the European Ethics Network, and publications. One of the most recent book is worth mentioning, Technology and Ethics. A European Quest for Responsible Engineering, because it is the first fully European contribution to the field of engineering ethics and the result of an intensive cooperation between ethicists and engineers from all the member countries of the European Union (Goujon \& Hériard 2001). This book deals first with the personal responsibility of engineers: it examines the role of professional codes and the fact that engineers must cope with flexibility, shorter lines of decision and erosion of the boundaries between private and professional life; it deals then with the institutional level of responsibility: aspects of decision making in the context of business organisations, such as quality management, technology assessment procedures, business ethics committees, etc... Finally it deals with the impact of technology on society and culture, and the power of technology.

There is also, at the level of the European Commission, a European Group on Ethics in Science and New Technologies (EGE), which is an independent, pluralist and multidisciplinary body which advises the European Commission on ethical aspects of science and new technologies in connection with the preparation and implementation of Community legislation or policies (EGE 2003). During its first mandate, the EGE (19982000) provided 5 "Opinions" on subjects as diverse as "Ethical Issues of human tissue banking', 'Ethical aspects of research involving the use of human embryo in the context of the 5th framework programme', 'Ethical issues of healthcare in the information society', 'Ethical aspects arising from doping in sport', and 'Ethical aspects of human stem cell research and use'. At a specific request of the President of the Commission, Romano Prodi, the Group has also produced a Report on the Charter on Fundamental Rights related to technological innovation: 'Citizens Rights and New Technologies : A European Challenge'.

We can conclude shortly saying that there is surely no vacuum in the literature, but rather a revival of the ethical preoccupation in the field of engineering. When I was a young student in engineering - 40 years ago! we had classes on the social role of engineers; the ethical questions were mainly confined in the field of financial uprightness and honesty! Steps forward have surely been achieved. 


\section{PROFESSIONAL ETHICS IN COMPUTING: FIRST STEPS}

Let us come now to a field which is to me more familiar: the 'Ethics of Computing'. We shall reflect first on the professional ethics of computing before enlarging the debate to the rather new phenomenon of self-regulation.

About traces of work on 'Ethics of Computing', I should remind a first one that I found in my archives, a text going back to 1966, hardly 20 years after the first computer was built: the ACM (Association for Computing Machinery) Guidelines for Professional Conduct of Information Processing. The British Computer Society which has played a leading role in promoting professional ethics in the Commonwealth was only chartered by the Privy Council, the Sovereign in Council, on July 31st 1984 (BCS 1984), but "it took the BCS almost ten years to meet the criteria required by the charter recognition, which covered, typically, such aspects as membership structure, educational standards governing eligibility for the membership grades, articles of association, rules and by-laws" (Sizer 1996). The October 1983 version of the BCS Code of Conduct, at my disposal, is however said as "superseding the previous issues". More and more the BCS stresses again today the qualification aspects. The last structural changes in 2001 made that the Ethics Committee now reports to the Qualifications and Standards Board, which replaces the old Professional Formation Board.

These ACM and BCS cases should emphasise that the conscience of 'professional ethics' was present since the 'birth' of the profession. What was stressed at the time (in the ACM Guidelines for instance) was specific behaviour in relation with the public, with employers and the clients, and with other professionals: competence in the profession, honesty, loyalty, meet the requirements and specifications of the clients, honour the profession, 'use his special knowledge for the advancement of human welfare',... The 1983 BCS code was stressing the quality of the professional conduct, the professional integrity, the respect of the public interest, fidelity, technical competence, impartiality. We shall come soon on the main content of the IFIP Codes. ACM Guidelines, BCS Code are clearly oriented towards "professionals".

But there is another story to remind, showing that things may be interpreted otherwise according to another approach of seeing the regulation of society. The Council of Europe (CoE 1979-82) has been working on the specific subject of 'legal problems connected with the ethics of data processing' for three years (1979-1982) without adopting a final resolution 
other than suggesting to explore 'legally' some more sensitive fields such as health care, social security, police, employment, payment and other related operations, etc. - what has been done later. The last report, prepared by Herbert Maisl for the Council of Europe, is dated September 14, 1982: 'Elaboration of an Analysis Framework for Rules of Different Nature related to the Management of Informatics'. It was examined during the meeting of September 27-30, 1982, and it was suggested to explore new problems, and to conclude the work which had been done, which meant abandoning the specific question of 'deontology' (CJ-PD[82]31, item 25). Before that decision, the Committee of experts 'Ethics of Data Processing' of the Council of Europe had questioned the European Data Commissioners Meeting (October 7-9, 1981). The second Report of Activities of the French Commission (CNIL) reports on it as follows: "The Council of Europe must take into account the spontaneous proliferation of rules of conduct as they appear in all the sectors where computers are present, and must suggest to the States Members new ways to explore, either legislative (new principles to set up), or supra-legislative (constitutional rules), or infra-legislative (recommendations or norms to be adopted by the control authorities, or directives coming from the Administration), or even infra-juridical (rules or codes set up by different organisations or associations)" (CNIL 1982). This statement of the Council of Europe debate introduces, without saying, the concept of multi-regulation which will be largely used later. It is also an expression of the compromise between a clear preference for a more normative and legal approach, and the place for 'infra-juridical' rules (the word in itself is interesting) but not for market laissez-faire.

Moreover, reflecting on this experience Prof. H. Maisl, who had been working for a long time on this issue for the Council of Europe, states that 'the rules of conduct have to reach, beyond the well structured body of computer scientists, the larger circle of computer users. We must shift, he says, from a deontology for informaticians to an objective deontology of informatics under the control of the law' (Maisl 1994).

\section{THE EXAMPLE OF COMPUTER SCIENTISTS AND PROFESSIONAL SOCIETIES WITHIN IFIP}

IFIP (International Federation for Information Processing) has no code of ethics or of conduct as an association. But its member Societies may have. We have reported at length on the experience of IFIP about ethics during the last 15 years (Berleur \& Brunnstein 1996). We have analysed some 30 IFIP Codes coming from countries mostly influenced by the Anglo-Saxon way of 
thinking. The rules within these codes are most of the time rather simple: $X$ is responsible about $\mathrm{Y}$ towards $\mathrm{Z}$. $\mathrm{X}$ is most of the time a member of the professional society. $Z$ is the employer, the client, the society as a whole, but also the profession itself. $Y$ is what we have called a responsibility field.

The responsibility field is, of course, the most developed part within the codes. Five main categories emerge and regroup the different wordings as adopted by the different computer societies - we give within parentheses the number of codes concerned by the mentioned wording, provided that it appears in at least one third of the analysed codes:

- Respectful general attitude (/30): This attitude includes respect for the interests or rights of the people involved (15), respect for the prestige of the profession (11), respect for the interests or rights of the public (10), and respect for the welfare, health of the public and for the quality of life (10).

- Personal (/institutional) qualities, such as conscientiousness, honesty and positive attitude, competence and efficiency (/30): In practice, the terms conscientiousness and honesty are frequently encountered under the expressions acceptance of responsibility (19) and integrity (26).

Moreover, appeals to respect for requirements or contracts or agreements (14) and to conscientious work (11) are also frequent.

- With regard to the expressions competence and efficiency, two other terms are very common: professional development and training (19) or limitation of work to the field of competence (18). Two others are also worth noting: general competence (13) and effectiveness or work quality (12).

- Promotion of information privacy and data integrity (/31):

Confidentiality (22) is required by nearly all the general codes of the IFIP societies (13/15). Privacy in general (14) and respect for property rights (12) are appealed to quite often. Other topics are: no computer crime, no information piracy or misuse [7],...

- Production and flow of information (/31): The majority of the codes (23) requires flow of information to involved parties or people. Information to the public (16) is also insisted upon. Half the whole set of codes calls for comprehensive information (14).

- Attitude towards regulations (/30): Regulations do not appear as a major theme. Less than half the codes requires respect for the code (13), respect for the law (13), and respect for IT and professional standards (12). Some consider sanctions against a breach of the code [9].

- Regulation of the code itself is often taken into account outside the code, in the procedures. 
First conclusions may be easily derived from this reminded analysis. We think that they could be similar for all the professional codes. The statements remain very general and fuzzy, and most of the time not specific to information and communication technology. On the five main responsibility fields, two are more or less directly linked to computing. And that is not yet quite sure: confidentiality was already considered in the topics enlightened by the Online Ethics Centre for Engineering and Science. General ethics, respectful general attitude, competence, quality, efficiency, accountability, fraud and property rights, as well.

The main recommendations of the IFIP Ethics Task Force to the IFIP member Societies, after its survey and analysis, were to develop more computer-related issues, to explore the most sensitive ones, to take into account the technical developments, to meet the challenges as mentioned by experts, to anticipate threats and dangers in specialised fields, to include the suggestions of international organisations (for instance the Council of Europe and its reflection on computer crime, or on privacy issues; the European Commission specialised groups),... (Berleur \& Brunnstein 1996; 257-268).

Other recommendations were made also about certain weaknesses of such professional codes, in the sanction levels, the disciplinary procedures, their updating process, the status of the different computer societies, and their membership structures.

\section{BEYOND PROFESSIONAL ETHICS: SELF- REGULATION DOCUMENTS}

As Herbert Maisl suggested after the Council of Europe experience on the 'Ethics of Data Processing', we have "to shift from a deontology for informaticians to an objective deontology of informatics under the control of the law."

What has happened? Clearly, in the field of 'ethics of computing', the nineties have been marked by the proliferation, outside of the professional societies and out of the control of the law, of different kinds of codes, guidelines, standards,...: 'The Ten Commandments of Computer Ethics' (CEI 1992), 'One planet, One Net: Principles for the Internet Era (CPSR 1997), The User Guidelines and Netiquette (Rinaldi 1999), The Wartburg Online Magna Charta (Magna Charta 1997). Curiously between 1997 and 1999, all the European associations of Internet Services Providers, regrouped in the EuroISPA, wrote their own Code/Guidelines of Conduct (EuroISPA). Other Codes came into light, covering more sectoral domains, such as the 
health sector, the publishing sector, eCommerce, software publishers, telemarketing,... IFIP-SIG9.2.2 has established an inventory and an analysis of such 40 documents (Berleur et al. 2000). The most developed analysis has been presented during the 17th IFIP World Computer Congress, in Montreal (Berleur \& Ewbank 2002). We here mention some of the most significant conclusions related to our purpose.

\section{Content}

The 'general principles' codes remain rather fuzzy, but they have a deontological content, sometimes in very normative terms: 'commandments'. They may include also consideration of correctness like the rules of Netiquette. They invite to the respect for others and for the work of the others. They could then be considered as belonging to the tradition of professional ethics or fair conduct. But they are also hardly enforceable, since there is no organisational structure and no procedure to promote and 'enact' them. They could be said 'inspirational'.

The study of the European ISPA codes shows 4 series of items at least which are recurrent in their preoccupation (for 8 codes). A recent European Commission project has confirmed our analysis (COCON 2002):

- 8 times: preoccupation about the "illegal material" (child pornography, racism propaganda,...), the necessity of youth protection especially against those who exploit their credulity, their commitment to cooperate with hotlines; but they also stress their incapacity of monitoring or controlling all their content;

- 7 times: data protection, confidentiality, email secrecy;

- 4 times: decency, no violence, no hatred, no cruelty, no incitement to commit crimes, no dissemination of propaganda material for unconstitutional organisations, respect for and care of human dignity, no ethnical, religious discrimination or on the basis of handicap or of expressed ideas;

- 3 times: fair trading, act decently with the customers, give them clear information, correct pricing information, etc.; one of them adding that they commit themselves not to promote illegal commerce!

About the sectoral codes, one could expect more specific clauses, since self-regulation is supposed to anticipate or supplement what cannot be included in the law. What clearly emerges is a more contractual character and the insistence on practices in accordance with the standards of the profession. Clauses of deontology become 'terms of services'. The Code of Ethics of the Internet Health Care Coalition, for instance, requires candour and trustworthiness, quality of information, products, services, the best 
commercial practices (our emphasis), the highest standards by Health Care Professionals (IHCC 2000). In the world of the online publishing, the French Charter reaffirms the usual rules of the profession; but they also go into details such as the number of paragraphs that can be quoted under fair dealing provisions, and without being accused of plagiarism, or specifies the rules related to links that may be created to online content (for example, links are authorised without condition provided the link opens a new window of the browser),... (Edition 2000)

In the domain of eCommerce, the 'Model Code of Conduct for Electronic Commerce' proposed by the 'Electronic Commerce Platform Nederland' (ECP-NL) offers typical clauses of good commercial practice: reliability of the information which is provided, reliability of systems and organisations, reliability of types of electronic signatures, transparency in the communication, confidentiality, respect for the intellectual property,... This code has now disappeared from the ECP-NL website!

The European Commission eConfidence Forum, started early 2000, seems also to be dormant (eConfidence 2001). It had produced documents such as 'General principles for generic codes of practice for the sale of goods and services to consumers on the Internet', 'Specific Guidelines for the interpretation of the general Principles', 'Guiding principles for 'approval and monitoring' bodies', and 'Options for 'Approval and Monitoring'.

The Global Business Dialogue on Electronic Commerce (GBDe) is quite more active: it holds one 'summit' each year, since 1999. Each summit provides recommendations. The last ones (Tokyo, 2001; Brussels 2002) were about consumer confidence, convergence, cybersecurity, digital bridges, eGovernment, intellectual property rights, Internet payments, taxation, and Trade/WTO (GBDe 2002). GBDe has also a Cyber Ethics Statement which is about questions linked to the diffusion of unethical material, like child pornography, anti-Semitic and xenophobic content, while fully protecting rights to free speech and expression, as well as artistic and journalistic freedom (wording of the GBDe Cyber Ethics statement) (Cyberethics 2001)! The Brussels 2002 Recommendations have now added a new chapter stressing what was until now a dissociated statement: 'Combating Harmful Internet Content.'

\section{Comments}

When looking so at more sectoral self-regulating instruments, it does become obvious that ethical concern is less apparent in the specialised work. What is becoming more prominent in this matter is contractual clauses. One 
example is given, for instance, in the "code of ethics" of the Internet Health Care Coalition (IHCC), which stresses, as we said, a clause about the best commercial practices.

But again, as in the case of professional codes, the clauses are fuzzy, and cannot reach the real target of protecting anybody against abuse. Their reading leaves more and more the impression that they are enacted by organisations for escaping legal liability, or for guaranteeing their own protection in case of legal proceedings.

In my opinion, the problem is multifaceted, but must be envisaged at the beginning from a double point of view: the content of the self-regulatory clauses and their development. The first question is: what are the specific issues which must be covered or not? What are the most acute ones, and from which point of view? What are the missing ones? And why? Lists of issues are numerous: we can refer, for instance to the PFIR list (People for Internet Responsibility): this list is probably too extensive to be manageable, but is interesting for consultation (PFIR 2001). The April 2003 issue of the ISOC Newsletter suggested: Cyber-fraud, Digital divide, On-line privacy, IT security, Intellectual property rights in cyberspace, Competition policy in the Internet, telecom, and IT sectors, Spam and on-line pornography, Spectrum policy for wireless Internet services. Recently, IFIP-TC9, in the Vilnius Declaration, insisted on the following issues: "Among the social and ethical concerns we strongly suggest a focus on professional ethics; access to content and technology for all; education, literacy and public awareness; multilingualism, cultural concerns; influence of globalisation; regulation, self-regulation, governance and democratic participation; intellectual property rights; specific digital policies such as eHealth, eWork, eGovernment, etc.; privacy; protection of human and civil rights; protection of the individual against surveillance; development of the quality of life and well-being; combating social exclusion; computer crime, cyber-attacks and security; employment and participative design at work; risk and vulnerabilities" (WITFOR 2003). The second question is related to the development of the issues. Most of the time, they are addressed in very short statements, where it is rather difficult to realise what is the real and mutual commitment of the parties. The statements are minimal; if not 'minimalist'. They are far from backing up or anticipating the law, as suggested by $\mathrm{H}$. Maisl in his first paper to the Council of Europe (CoE 1979-82).

Then come other questions related to the legitimacy of the selfregulation instruments, and their efficiency. When speaking about their legitimacy, we cannot escape questions such as: Who is enacting, and how? Who are the authors, and how are the people concerned by the rules consulted? Is it during the process any participation of users, consumers, 'usees' (affected people)? What is the transparency of the elaboration 
procedures? How do the norms conform with the content of norms of higher rank? Where are the norms received and by whom? The question of legitimacy must be scrutinised with the highest care: it becomes the condition for the rules to be accepted. Unfortunately, too much is left to the discretion of the authors who enact the rules without offering any transparency, or even clarity, particularly to the people concerned and the general public. It appears that participation in making the norms is low, if not non-existent, and that actors impose on society norms which are discussed nowhere.

The question of efficiency is more related to the enforcement, the complaint procedures, and the dispute resolution. Most of the time, something is said about enforcement, but it is not easy to see how it functions: it is suggested to remove the service to a client who contravenes the rule, or to suspend the membership to a provider, for instance. But to enforce rules at an international level remains absolutely uncertain. Regarding the complaint mechanisms, they are mentioned very often, but they are not really developed, and the body who receives the complaint is rarely independent from the authors who have enacted the rules. Sanctions are also vaguely foreseen. The idea of "Alternative Dispute Resolution" (ADR) and of Cybermagistrates is going its way (ECODIR 2001). Systems of labelisation, such as BBBOnline, or WebTrust raise also new questions: methods for removing labels and the actual security of the labels appear to be in some doubt; there is no information available about how satisfactory the procedures are, what monitoring of the effectiveness of the measures there is, etc. (Gobert \& Salaün 1999).

The slogans of self-regulation, 'The least State possible is the best', 'Let us avoid a greater degree of statutory regulation', or 'Let business selfregulate the Net' belong to the "knee-jerk antigovernment rhetoric of our past", and cannot persist without damage for a democratic society (Lessig 1999). They are societal lies.

\section{... AND ETHICS?}

Ethics is recognised as helping people to take more conscious and responsible decisions and act accordingly. The first question is thus: are professional deontology and self-regulation adequate instruments for that purpose?

The distinction must be made between what is related to the profession on the one side, and to society on the other. The profession has most of the time boundaries which can be more or less delineated, society not. This has 
deep consequences on the ethical content of the norms, due to cultural, social, legal differences, but also on the way to conceive the enforcement, the suing procedures,... The transfer of the rules from the first one to the other will be most often undue.

The functions of codes in professional deontology have been relatively well studied. We already reminded most of them in another publication, concluding: "It appears clearly that there are functions which are oriented for the sake of the profession itself - the adherence to it, its identity, the assurance of competence, the way to regulate internal conflicts, ... But there are also functions which define the boundaries between the profession and the society: they allow the public to have a look at it, or the society to know what is happening in it; they act as an appeal for responsibility at different levels - firms, society, etc." (Berleur 1996). What happens when the boundaries of the profession are unclear, as it is precisely the case for the computing profession? Again, the answer is not obvious, and depends, for instance, upon the strength of the computer societies in a country or a region. The case of the profession does not seem to us insurmountable. Ethics can find its place because member participation and public democracy are possible.

The situation of self-regulation is not the same. One could say that when it becomes more sectoral, its status is not quite different from the profession. But we have seen that when we are leaving the general principles of the deontological approach for more specific principles we are led to contractual terms, and ethics is more and more absent. We have also said that our deep conviction after having read and analysed those documents is that they are more self-protecting than self-regulating, which is the opposite of giving the public the capacity of knowing and evaluating the way our societies are facing their future. The relationship between self-regulation and the law must thus be clarified. And as professional deontology was functioning in the double role of supplementing and anticipating the legal regulation, we may wonder if the law has not to fix the framework for selfregulation. At least the representative democracy could interfere at one moment in a process which later seems more and more escape to its control. The State has not to rule everything. But it must define as clearly as possible, and in a transparent manner, the principles and the values that it wants to be respected.

In both cases, there is also a need to go further into more specific issues related to specialised fields. In other words, professional deontology as well as self-regulation must become more and more early warning. 'Specialists' are the only ones to have the capacity of such technology watch; they are in the responsibility of anticipating the future, not only in its technological dimension, but also in the social and ethical ones. But they cannot deal with 
that without the full participation of all people involved in the different processes. Ethics and democracy are merging together, today more than ever.

We could say that there is a future for professional deontology provided at least that it deepens the computer-related and information society issues, whilst there will be no future for self-regulation unless it clarifies democratic and participative approaches, and accepts a legal regulatory framework.

\section{TO SUM UP... WITHOUT CONCLUDING}

In my opinion, we should:

- Request more professionalism from professional bodies, i.e. clearer statements on issues in specialised fields where they develop their competence;

- Anticipate threats and dangers;

- Increase international exchange between professional societies and institutional groups, respecting the cultural, social, and legal differences;

- Reflect on the "shift from deontology for informaticians to a deontology of informatics under the control of the law";

- Question self-regulation in terms of improvement of commitment and responsibility of organisations. Is it not too minimalist?

- Increase self-regulation legitimacy by promoting large participation of all the concerned parties;

- Refrain from slogans of the past, such as "Let business self-regulate the Net" which are at risk of damaging societal fabric, and which are not favouring the cooperation between private and public;

- Clarify the relationship between deontology, self-regulation, the law, and ethics.

What Information Society needs is 'early warning', anticipating the different dimensions - including ethics - of social life. Information Society is not a technological concept, but first a social choice: it must have its norms, supported especially by ethical values.

\section{REFERENCES}

(BCS 1984): The BCS Royal Charter: http://www1.bcs.org.uk/homepages/512/ On the Privy Council and the Chartered Bodies, see : http://www.privy-council.org.uk 
(Berleur 1996): Jacques Berleur, Final Remarks, in : (Berleur \& Brunnstein 1996), pp. 244245.

(Berleur \& Brunnstein 1996): Jacques Berleur \& Klaus Brunnstein, eds., Ethics of Computing: Codes, Spaces for Discussion and Law, A Handbook prepared by the IFIP Ethics Task Group, op. cit.. The background history is to be found in: Jacques Berleur and Marie d'Udekem-Gevers, Codes of Ethics/Conduct for Computer Societies: The Experience of IFIP, in (Goujon \& Hériard 2001; pp. 327-350).

(Berleur et al. 2000): Jacques Berleur, Penny Duquenoy, Marie d'Udekem-Gevers, Tanguy Ewbank de Wespin, Matt Jones and Diane Whitehouse, Self-Regulation Instruments Classification - A Preliminary Inventory, (HCC-5, Geneva 1998; SIG9.2.2 January 2000; SIG9.2.2 June 2000; IFIP-WCC-SEC2000), (C) IFIP-SIG9.2.2 http:/www.info.fundp.ac.be/ jbl/IFIP/sig922/selfreg.html

(Berleur \& Ewbank 2002): Jacques Berleur and Tanguy Ewbank de Wespin, Self-regulation: Content, Legitimacy and Efficiency - Governance and Ethics, in Human Choice and Computers, Issues of Choice and Quality of Life in the Information Society, Klaus Brunnstein \& Jacques Berleur, eds., Proceedings of the IFIP-HCC6 Conference, $17^{\text {th }}$ World Computer Congress, Montreal, August 2002, Kluwer Academic Publ., 2002, pp. 89-108.

(CEI 1992): The Computer Ethics Institute (CEI), Washington, D.C., The Ten Commandments of Computer Ethics, 1992 http://www.brook.edu/its/cei/cei hp.htm

(CNIL 1982): Commission Nationale de l'Informatique et des Libertés, Deuxième Rapport d'activités, ler octobre 1980 - 15 octobre 1981, Paris, La Documentation française, 1982, p.158.

(COCON 2002): Centre for socio-legal studies, University of Oxford, IAP Codes, COCON, Codes of Conduct, http://selfregulation.info/cocon/index.htm

(CoE 1979-82): Council of Europe, Committee of experts on Ethics of Data Processing, Herbert Maisl, Legal Problems Connected with the Ethics of Data Processing, Study for the Council of Europe (CJ-PD[79]8, Strasbourg, August 29, 1979; Report of Working Party $n^{\circ} 3$ on the Ethics of Data Processing (CJ-PD[80]1); Summary of a Draft Code of Conduct prepared for the Netherlands Society for Data Processing (CJ-PD-GT3[80]1); Ethics of Data Processing (CJ-PD-GT3[81]1); The Ethics of Data Processing (CJPD[81]5); Ethics of Data Processing, Categories and Roles in the field of Data Processing (CJ-PD-GT3[81]2 revised); Secretariat Memorandum (CJ-PD[81]8), and the last report: Herbert Maisl, September 14, 1982: 'Elaboration of an Analysis Framework for Rules of Different Nature related to the Management of Informatics' (CJ-PD[82]19), with the Minutes of the Meeting (CJ-PD[82]31).

(CPSR 1997): CPSR (Computer Professionals for Social Responsibility), One planet, One Net: Principles for the Internet Era, 1997, http:/www.cpsr.org/program/nii/onenet.html

(Cyberethics 2001): Global Business Dialogue on Electronic Commerce, Statement of Principles on Cyber Ethics, Tokyo, September 14, 2001, pp. 30-32.

(ECODIR 2001): Electronic Consumer Dispute Resolution, http://www.ecodir.org

(eConfidence 2001): European eConfidence Forum, http://econfidence.jrc.it/

(Edition 2000): Charte de l'édition électronique (Le Monde, Libération, ZDNet, La Tribune, Investir, Les Echos, L'Agefi, France) : rights and duties of the consumers, editorial content, copyright and intellectual property rights, http://www.liberation.fr/licence/charte.html

(EEN 2003): European Ethics Network: A Forum for Ethics in Europe, http://www.kuleuven.ac.be/een/Contents/introduction.html 
(EGE 2003): The European Group on Ethics in Science and New Technologies, http://europa.eu.int/comm/european_group_ethics/index_en.htm

(EuroISPA): European Internet Services Providers Association, http://www.euroispa.org

(GBDe 2002): Global Business Dialogue on Electronic Commerce, Brussels Recommendations, October 29, 2002, http://www.gbde.org

(Gobert \& Salaün 1999): Didier Gobert et Anne Salaün, La labellisation des sites Web : inventaire des initiatives existantes, in : Communications \& Stratégies, 1999, n 35, pp. 229 - 251. Better Business Bureau Inc., BBBOnLine, Code of Online Business Practices, Draft 1999, http://www.bbbonline.org/code/code.asp WebTrust Certification Services for E-Commerce Web Sites, http://www.webtrust.net/

(Goujon \& Hériard 2001): Goujon Philippe, Hériard Dubreuil Bertrand, eds. Technology and Ethics, A European Quest for Responsible Engineering, European Ethics Network, Peeters, Leuven, 2001.

(IHCC 2000): eHealth Ethics Initiative, eHealth Code of Ethics, http://www.ihealthcoalition.org/ethics/ethics.html

(Lessig 1999): Lawrence Lessig, Code and other Laws of Cyberspace, Basic Books, New York 1999.

(Magna Charta 1997): Online Magna Charta, Charta of Freedom for Information and Communication, 'The Wartburg Charta', 1997, http://sem.lipsia.de/charta/gb/chartagb.htm

(Mais1 1994): Herbert MAISL, Conseil de l'Europe, protection des données personnelles et déontologie, in: Journal de Réflexion sur l'Informatique, no. 31, Namur (Belgique), Août 1994.

(OECES 2003): Online Ethics Center for Engineering and Science (OECES) at CASE Western Reserve University, http://www.onlineethics.org

(PFIR 2001): People for Internet Responsibility, Issues, Version of July 4, 2001, http://www.pfir.org/issues

(Rinaldi 1999): Arlene H. Rinaldi, The Net: User Guidelines and Netiquette, 1998, http://www.fau.edu/netiquette/net/

(Sizer 1996) Richard Sizer, A Brief History of Professionalism and its Relevance to IFIP, in : Jacques Berleur \& Klaus Brunnstein, eds., Ethics of Computing: Codes, Spaces for Discussion and Law, A Handbook prepared by the IFIP Ethics Task Group, London: Chapman \& Hall, 1996, ISBN 0-412-72620-3 (now available at Kluwer Academic Publishers, Boston), pp. 56-60.

(WITFOR 2003): World Information Technology Forum, The Vilnius Declaration, August 29, 2003, http://www.witfor.lt 